\title{
INNOVATIVE APPROACHES TO TEACHING ENGLISH LANGUAGE TO ARTISTS
}

\author{
Iryna Ghritchenko \\ Pavlo Tychyna Uman State Pedagogical University, Uman, Ukraine \\ gritchenkoirina@ukr.net \\ Inna Nesterenko \\ Pavlo Tychyna Uman State Pedagogical University, Uman, Ukraine \\ innusya6@mail.ru
}

\begin{abstract}
The article highlights the problem of foreign language training of future artists in higher educational establishments. The main feature of English for specific purposes (ESP) is a professionally oriented approach to learning English. It involves the formation of students' ability to foreign language communication in specific areas and situations. Permanent and variable characteristics of a foreign language for specific purposes are given. The main issues of studying ESP by art students include the specifics of lexical content and special format of oral and written texts related to the profession. With the help of dominant perceptual modality diagnostics by S. Yefremtsev, we have defined that $95 \%$ of all respondents refer to the visual type. The common features of visuals were taken into account in creating the system of classes based on the communicative approach and the principle of visual perception of information. The article analyses the content and feasibility of the ESP textbook specially created for future artists. Main lingodidactic (general teaching) principles of training of speech activity types are described. They include: specific professional area, complexity and interconnectedness of learning types of speech activity, dominance of one type of speech activity at a certain stage of training, learning objectives, gradual and consistent skills formation, the text as a basis for any kind of speaking, the richness of analytical tools in every form of speaking, facilities, and advanced technology training. The article proves the necessity of using Internet resources in teaching ESP.
\end{abstract}

Keywords: artists; foreign language training; English for specific purposes; language activity; communicative approach; the principle of visual perception of information; new education technologies.

\section{Introduction}

The key issue of any education system is training professionals in a respected field. The integration processes in society lead to the increased demand for professionals who speak foreign languages because it enables students and graduates of non-philological faculties realise their social and professional mobility. For this reason, today, teaching a foreign language focuses on professionalisation to enable students to use foreign languages as a tool for a future career.

The present research suggests new approaches to foreign language training to artists. The specific objectives are: to describe a system of classes based on the communicative approach and the principle of visual perception of information; to provide methodology of creating English for specific purposes (ESP) textbooks for future artists, discuss their contents and feasibility of using; to characterise main lingo-didactic (general teaching) principles of training speaking skills, taking into account the specific professional area.

\section{Professionally oriented English language training}

Professionally oriented approach to teaching English involves the formation of students' ability to communicate in a foreign language in specific areas and situations: professional, business, scientific, educational and research (Pokushalova, 2005, p. 305). Within this approach, the students' need of learning a foreign language related to the future profession (such as learning English by future artists) is taken into account. The term "professionally oriented education" refers to the process of teaching English in nonlinguistic faculties, based mainly on reading professional literature, studying professional vocabulary and terminology, communicating in the professional field.

Some scholars argue that a General English course follows "one size fits all" scenario. This course can be called "English for no purpose"; it teaches language for the sake of accumulating vocabulary units that a person might never need to use (Long, 2005, p. 19). The narrow approach to a foreign language for specific purposes focuses on restricted language repertoire, teaching terms, and specific discourse (Huckin, 2003, p. 3-17; Hyland, 2003, p. 17-29).

While speaking about professionally oriented education, we should mention professionally oriented communicative language teaching as an effective approach widely supported by scientists and teachers. It involves learners in authentic environment and communication and helps develop the communicative competence of non-native speakers studying ESP. Alvermann \& Moore (2011) note that "interactive 
communication technologies and a definitional broadening of text to include moving images, words, sounds, gestures, and performances support the folding of literacy practices, regardless of their place of origin" (p. 157).

\section{Permanent and variable characteristics of English language teaching}

In recent studies, English language teaching specific characteristics and its differences from the General English are divided into permanent and variable. Among the permanent ones the following characteristics are distinguished (Dudley-Evans A., 1998): English language teaching for specific purposes (ELTSP) meets the specific student's needs; uses methods and techniques peculiar to the certain field of knowledge (methodology of special subjects); is based on language (vocabulary, grammar), genre and discourse of specific texts.

Variable characteristics are the following: ELTSP program can be developed in various subject areas; in certain situations, in ELTSP, different methods comparing to General English teaching may be used; usually, ESP programs are developed for students and employees of a particular industry; ELTSP presupposes that students have mastered a basic knowledge of English.

In teaching English to future Artists it is necessary to take into account the specific lexical units and specific format of oral and written texts. The professional focus of teaching practice includes integration with the majors as well as forms and methods to ensure the formation of necessary professional skills and knowledge (Gal'skova N. D., 2000).

Under these conditions, the researchers believe that the creation of ESP interdisciplinary courses which will combine the content of various subjects is very perspective (Alekseeva, 2007). ESP can become a subject to learn and also a tool for the formation of professional skills. This is possible with the use of professionally oriented training materials and activities (Pokushalova, 2005).

Today ESP for future artists is taught at Ukrainian universities under the current program in English for professional communication in which the content of education has to: 1) be based on international levels of proficiency; 2) meet national standards; 3) have clearly defined goals and learning outcomes; 4) develop professional and educational skills; 5) cover professional, academic, situational and pragmatic content; 6) take into account the previous experience of students, their requirements and training needs; 7) be modular in its organisation.

The major criteria for determining the training content are the analysis, carried out by the poll of students, professionals, employers, subject teachers and ESP teachers; testing students; interviews and analysis of job descriptions; conducting pre-project study of English for professional communication, etc. (Bakajeva, Borysenko \& Zujenok, 2005, p. 6). The ESP features discussed above, in particular, the necessity to consider students' needs in their future careers and the importance of general education (vocational, academic, situational content) disciplines, and the focus on the international level of proficiency, developed primarily for General English, are taken into account.

\section{The diagnosis of the dominant perceptual modality in future artists}

To choose the best technology for foreign language teaching to future artists we have used the dominant perceptual modality diagnostics, developed by Yefremtsev (Fetiskin, Kozlov \& Manujlov, 2002) to determine the leading type of perception ("visual", "kinesthetic", "auditory"). Each person has leading body senses that more quickly respond to external signals (visual, tactile, auditory). Having defined the leading type of perception, (95\% of all respondents were visuals), we made a couple of observations and identified their common features to be taken into account in designing further strategy foreign language acquisition. They are the following:

- visuals are not influenced by outside noise;

- visuals memorise material in pictures and frames;

- it is important for visuals to have everything around them beautiful;

- visuals love inventing and dreaming;

- sight and hearing for visuals are a single system (if they do not see something they do not hear);

- communication with a visual should contain words that describe the colour, size, shape, location,

highlighting various aspects of content or items; using charts, tables, visual aids, etc.;

- visuals prefer to have the information they need to be recorded on the board;

- visuals are able to solve problems quickly;

- visuals need a handy leaflet to draw in the process of understanding and memorizing new material. 
Visuals are mostly creative people who perceive the external world through images, fantasy, imagination. Vision plays a major role in this process. Often they are characterised by intensive gestures because they do not have enough words to fully describe their thoughts. This is because visuals think in pictures, having more colours than words. Such people have excellent visual memory. Quite often they can easily recreate the required information from a book page.

\section{Textbooks and curriculum}

Taking into account the above-mentioned characteristics and features, we have developed a foreign language textbook for future artists "English for Artists" and its electronic addition - e-book "English for Artists", supplementing the basic book by vivid illustrations, examples and art videos.

The manual consists of 4 themes (modules): "Essential Art Know-How", "Colour Theory and Mixing", "Different Kinds of Painting", "Modern Art". Each of these topics includes a set of basic texts with a list of terminological vocabulary for active learning and a series of pre- and post-text vocabulary exercises to form different types of speech activity. There are also creative tasks, focused on training active vocabulary and its use in communicative situations, following the principles of consistency and continuity in the transition from simple to more complex speech acts.

The textbook is aimed at developing in students the basic skills in reading and understanding the original literature on specialty, teaching art vocabulary to be used in professional communication.

For the convenience, the textbook was created using the system of 3-level tasks. The first task type is a reproduction and it involves simple exercises to consolidate vocabulary or comprehension. The second task type is that of increased complexity, it involves the set of exercises not only in vocabulary but also in grammar. In addition, there is an analysis of the world-famous paintings. The third task type is creatively communicative, it provides the establishment of dialogue situations, computer presentations, group discussions, helpful videos view and other creative tasks (for example, the textbook illustrators were also made by art students).

All classes are built on the basis of visual perception of information. Each class prepared presentations, videos, simplifying the assimilation of information by students. Moreover, taken into account the creative potential of future artists, most tasks are creative, with elements of critical thinking.

\section{Communicative approach to teaching future artists}

However, teaching ESP to future artists is based not only on psychological, but the main linguodidactic (general teaching) principles of training types of speech activities among which:

- The complexity and interconnectedness of learning types of speech, important criteria of which are: simultaneity, sequence-time correlation, common language material, special series of exercises (preparation, training, speech), etc. It is worth noting that the kinds of speech do not exist separately, they are somehow closely related. We agree with the opinion of Polish researchers Seretny \& Lipińska (2000) who emphasize the interdependence of listening and speaking and note that "you cannot say anything without listening to yourself while speaking, that is without monitoring of features and expression by ears" (p. 140). They also point out the relationship of writing with reading, because both species "are the realisation of manual-visual communication" (p. 230). For example, writing cannot exist without reading, as one who writes needs to read their text. Thanks to reading speaker's vocabulary increases, knowledge of practical stylistics enriches.

- Dominance of one type of speech activity at some training stage due to the intensification of the educational process requirements. The mechanism of formation of one type of speech activity is subject to all of the system. Initially, this is speaking, on the pre-intermediate stage - listening, advanced - reading, final writing. However, in the process of development at some stage one of the types of speech activity continuously improving primary one - speaking, while one of the main types of language learning is generally considered listening (Stankevych, 2007, p. 40-47).

- Learning objectives. The main task of the teacher is to be able to distinguish the most important in the case and direct training in the right way. Different types of speech activities require certain professional skills of the future specialists. The ability to speak for future artists is the ability to reproduce the spontaneous speech; to engage in dialogue; to provide people with the information on arts; to read written text in specialty aloud; to talk about paintings they made, give an oral analysis of fine artwork, etc. In the process of writing learning they should strive to be able to: write an art article, present a picture; write art essays, paintings descriptions, abstract from the text in specialty; make a record for future reference; write under dictation; write fiction, etc. During training listening comprehension future artists should acquire the skills of listening and understanding texts in specialty, interviews of famous artists and art critics, involuntary hearing talk of other creative people. Reading involves the reading with the purpose of general 
orientation in art subjects; to obtain information about the paintings and artists; for instruction execution (of artistic experimentation), for pleasure. Through activities such as drama and storytelling, art, discussion, drawing and dance, student's outer play encourages the inner play of imagination, developing their flexibility with ideas and language (Cremin \& Maybin, 2013, p. 275).

- Gradual and consistent formation of skills. A characteristic feature of each type of speech is primary mechanisms that shape the knowledge which in turn is transforming into skills. For example, listening develops such initial mechanisms as intonation and phonemic hearing, forecasting probability, proactive perception, memory, speech level segmentation, identification of concepts, etc. Then we develop the skills of recognition of words, understanding of the certain sentences, understanding the structure of the text, which in turn transform during the learning process into the ability to listen and understand the meaning of reading material.

- The text as a basis for any kind of speaking. In the process of ESP teaching to art students, we should take into consideration the specifics of specialty texts formation and peculiarity of text language tools of all functional styles. Taking into account the actual communicative needs of students, we selected a certain set of requirements for each type of speaking, including scope, degree of descriptiveness, complexity of linguistic material, logical and compositional structure etc. Also, the accent was given to the general principles of texts selection for teaching, namely, the originality of the work; the logical conclusion of the text, matching its educational and training purposes.

- The richness of analytical tools in every form of speaking. Whereas certain types of speech are common, this necessitates methodical approaches to their learning. For example, work with text for reading and audio text are based on common criteria for selection of these texts (informational, educational, linguistic, structural), common logical-semantic and stylistic analysis, similarity exercises (pretext designed to remove the geographic, lexical, grammatical and stylistic difficulties; in text - forming communicative guidelines; post text - control comprehension). Speaking and listening exercises provide a similar classification for language and speech (preparations and training). Types of exercises depend on the nature and subspecies of speaking, such as the system of learning to read - sight reading, scan reading, reading to study; in speaking - monologue speech, dialogical speech; in teaching writing - controlled, guided, free, etc. (Stankevych, 2007, p. 40-47).

- Technical equipment and advanced learning technologies. The use of technical tools in the study of the English language has been a common phenomenon in our practice because they contribute to the intensification and efficiency of training. They can provide students with specific vocabulary and provide learning and language use in their profession; prepare students to read and understand the original art literature, developing thus the skills of foreign language communication in certain situations and communication within prescribed program subjects. Training is based on visual perception, which is impossible without diagrams, tables, figures, pictures, maps, posters, videos, etc. In addition, students not only passively accept information but also actively participate in its creation. They "surf" Internet, looking for interesting information about the artists, their paintings, modern art and its peculiarities. Future specialists create art blogs and presentations, using social networks to directly assist teachers in carrying out independent work, comment on their observations on the artistic forums.

In our training, we used a large number of interactive activities, such as work in pairs and small groups; "Brainstorm", various discussions etc. Students made annotations of authentic articles that highlight the most important events in the art world. They wrote paintings that reflect the geographic aspect of learning a foreign language and the creation of these personal exhibitions. All of that opened students' creative potential, helped them express themselves and better understand their future profession, have a creative state of mind. These features are closely interrelated and are fostered in schools which profile creativity, expect the unexpected and encourage the professional autonomy of the teaching staff, enabling them to take supported risks as they collaborate with one another and the children on their learning journeys (Cremin, 2015, p. 44).

\section{Conclusions}

It should be noted that in the context of globalisation and integration in society there is a growing demand for professionals with knowledge of a foreign language with the possibility of their free exchange of ideas and information. The educational, scientific and professional mobility encourage students to study a foreign language as a means of obtaining new knowledge of their profession, sharing the research with scientists from other countries, the implementation of future professional activity. Emphasis is placed on learning a foreign language for specific purposes as a means of becoming a specialist, professional knowledge, and tools for professional self-improvement. 
Nowadays foreign language training of future artists is performed in the context of the new approach, namely "professionally oriented education". It involves the formation of ability to foreign language communication in specific fields and situations. This term refers to the process of teaching English to nonlinguistic faculties, based mainly on reading professional literature, studying professional vocabulary and terminology, communication in the professional field that is significantly different from learning English for general purposes. The main feature of learning ESP by students-artists are the specifics of lexical content and format, specific oral and written texts aimed at developing professional foreign language competence and focused on shaping student's ability to adequately use English in accordance with the professional, scientific research or business situations, the skills necessary to obtain the information from foreign sources.

With the diagnosis of the dominant perceptual modality, we have chosen the strategy of leading type of future artists' perception as one of the best technologies of teaching foreign language for professional purposes. As a result, it is determined that students of art specialties refer to visuals. The students of this type use sight as leading body sense, through which future artists perceive the world around them, because they think by visual images, having more colours than words.

Article's attention is also focused on the development of the textbook in a foreign language for future artists "English for Artists" and its electronic version - e-book "English for Artists", the use of which will help enhance students' interest in future profession, self-control, their success in learning a foreign language, make them actively participate in the learning process. The textbook is built in accordance with the module system and includes texts and audio parts, schematic graphic images, tables, videos, animations, interactive units. Most tasks are imaginative, with elements of critical thinking because of the creative potential of future artists. It makes the learning process more productive.

\section{References:}

Alekseeva, L. E. (2007). Metodyka obuchenyja professyonaljno oryentyrovannomu inostrannomu jazyku. Kurs lekcyj [Technique of training to professionally focused foreign language. Lecture course]. Moskow, Russia: Fylologhycheskyj fakuljtet $\mathrm{SPbGhU}$.

Alvermann, D. E., \& Moore, D. W. (2011). Questioning the separation of in-school and out-of-school contexts for literacy learning: An interview with Donna E. Alvermann. Journal of Adolescent \& Adult Literacy, 55(2), 156-158. http://dx.doi.org/10.1002/JAAL.00019

Bakajeva, Gh. Je., Borysenko, O. A. \& Zujenok, I. I. (2005). Proghrama z anghlijsjkoji movy dlja profesijnogho spilkuvannja [Program in English for Professional Communication]. Kyiv, Ukraine: Lenvit.

Cremin, T. \& Maybin, J. (2013). Children's and teachers' creativity in and through language. International Handbook of Research on Children's Literacy, Learning and Culture. Oxford, UK: Wiley Blackwell.

Cremin, T. (2015). Creative teachers and creative teaching. In: Wilson \& Anthony (ed.) Creativity in Primary Education (2nd ed.). Exeter, UK : Learning Matters.

Dudley-Evans, A. \& John, St. (1998). Developments in English for Specific Purposes: A multi-disciplinary approach. Cambridge, UK: Cambridge University Press.

Fetyskyn, N. P., Kozlov, V.V., \& Manujlov, Gh. M. (2002). Socyaljno-psykhologhycheskaja dyaghnostyka razvytyja lychnosty y malykh ghrup [Socio-psychological diagnosis of personality development and small groups]. Moskow, Russia: Izd-vo Instytuta Psykhoterapyy.

Ghaljskova, N. D. (2000). Sovremennaja metodyka obuchenyja inostrannomu jazyku: posobye dlja uchytelja [Modern methods of foreign language teaching: Teacher Guide]. Moskow, Russia: ARKTY Ghlossa.

Huckin, T. (2003). Specificity in LSP. Utah, USA: IBERICA, 5.

Hyland, K. (2003). Genre-based pedagogies: a social response to process. London, UK: Journal of Second Language Writing, 12 (1).

Long, M. (2005). Second language needs analysis. Cambridge, UK: Cambridge University Press.

Pokushalova, L. V., \& Serebrjakova, L. T. (2005). Obuchenye professyonaljno oryentyrovannomu jazyku v tekhnycheskom vuze [Teaching a professionally-focused foreign language at non-linguistic universities]. Moskow, Russia: Molodoj uchenyj.

Seretny, A. \& Lipińska, E. (2000). ABC metodyki nauczania języka polskiego jako obcego [ABC methodology of teaching Polish as a foreign language]. Kraków, Poland: Universitas.

Stankevych, N. (2007). Vydy movlennjevoji dijaljnosti v aspekti linghvodydaktyky.Teorija i praktyka vykladannja ukrajinsjkoji movy jak inozemnoj [Types of speaking in terms of linguistics. Theory and practice of teaching Ukrainian language]. Ljviv, Ukraine : Vydavnychyj centr LNU imeni Ivana Franka. 